\author{
Magdalena CYREK ${ }^{1}$
}

\title{
ŚWIATOWE DYSPROPORCJE W SEKTOROWEJ STRUKTURZE ZATRUDNIENIA KOBIET I MĘŻCZYZN
}

\begin{abstract}
Procesy globalizacyjne dynamizują zmiany strukturalne przebiegające w kierunku gospodarek postindustrialnych opartych na wiedzy, w których dominują relacje o charakterze usługowym. Wpływają także na przekształcenia stosunków społecznych, określających pozycję osób odmiennej płci na rynku pracy, oraz modyfikują obszary współcześnie występujących nierówności społecznych.

Wobec tych zmian w opracowaniu badaniom poddano się różnice w trójsektorowej strukturze zatrudnienia kobiet i mężczyzn występujące pomiędzy gospodarkami państw świata. Dokonano analizy tych zróżnicowań w grupach państw cechujących się odmiennym poziomem rozwoju społeczno-gospodarczego, określanym przez poziom dochodu narodowego brutto na mieszkańca. Weryfikacji poddaje się tezę o zmniejszaniu się dysparytetów między osobami różnej płci w zakresie zaangażowania w sektorach rolnictwa, przemysłu i usług wraz z rosnącym poziomem dobrobytu. Taki kierunek zmian wynikałby z rosnącego znaczenia walorów intelektualnych potencjalnych pracowników i posiadanej przez nich wiedzy dla możliwości zatrudnieniowych. Sugerowałby również zanikanie stereotypów płci i różnic kulturowych w postrzeganiu ról społecznych kobiet i mężczyzn.

Przedstawione wyniki analiz wskazują jednak na narastanie dysproporcji w zakresie obszarów zatrudnienia kobiet i mężczyzn wraz z rosnącym poziomem dochodu na mieszkańca. Prezentowane dane dowodzą wysokiej feminizacji sektora usług oraz tworzenia miejsc pracy faworyzujących mężczyzn w procesie industrializacji. Sugerują więc wciąż niski stopień rozwoju gospodarek opartych na wiedzy, dominację utrwalonych kulturowo stereotypów płci, sygnalizują również wykształcanie się nowych linii podziału społecznego oraz zniekształcający charakter oddziaływania polityki społecznej.
\end{abstract}

Słowa kluczowe: struktura zatrudnienia, płeć, sektory ekonomiczne

\section{WPROWADZENIE}

Gospodarki wszystkich państw świata podlegają głębokim zmianom strukturalnym, które są stymulowane przez intensyfikację zjawisk globalizacyjnych. Pomimo obserwowanej współcześnie dynamizacji przekształceń zmiany w dystrybucji czynników wytwórczych, w tym siły roboczej, pomiędzy sektorami pozostają procesem długookresowym i ewolucyjnym. Warunkowane są zdolnościami adaptacyjnymi pracowników, wynikającymi nie tylko z ich wiedzy, umiejętności, motywacji, ale i wzorców kulturowych, które ukształtowały się w wyniku historycznego rozwoju relacji społecznych i cechują silną inercją. Występowanie nierówności strukturalnych, wynikających z „tradycyjnych” różnic między grupami społecznymi nakłada się na zjawiska generowania nowych, dynamicznych nierówności, na które mają wpływ rozwój technologiczny, zmiany prawne czy przekształcenia relacji społecznych. Wskazuje się przy tym, że w globalnym świecie wśród

${ }^{1}$ Dr Magdalena Cyrek, Katedra Teorii Ekonomii i Stosunków Międzynarodowych, Wydział Ekonomii, Uniwersytet Rzeszowski, ul. M. Ćwiklińskiej 2, 35-601 Rzeszów, tel. 178721717. 
czynników determinujących wzrost nierówności zyskują na znaczeniu: kapitał finansowy, informacja, nauka i zasoby produkujące wartość - środki przechowywania i transportu kapitału, informacji i wiedzy ${ }^{2}$.

Determinanty te wyznaczają również rolę kobiet i mężczyzn w społecznym podziale pracy, w tym w ramach rynkowej sfery aktywności gospodarczej. Dystrybucja sektorowa osób różnej płci może stanowić więc wyznacznik ich pozycji społecznej i skali zjawisk dyskryminacyjnych. Kategoria płci może być przy tym rozumiana w sensie zarówno biologicznym, jak i kulturowym, związanym ze społecznym tworzeniem koncepcji męskości oraz kobiecości i odnoszącym się do cech nabytych: atrybutów, postaw, ról społecznych i zachowań przypisanych mężczyźnie bądź kobiecie ${ }^{3}$. W kontekście kształtowania płci społeczno-kulturowej należy zaznaczyć globalną tendencję do wzrostu znaczenia idei równouprawnienia płci wraz ze stabilizacją systemów demokratycznych i osiaganiem wyższych wskaźników rozwoju ekonomicznego ${ }^{4}$. Stwarza to przesłankę do dalszych minimalizacji dysproporcji płci w uczestnictwie w sferze aktywności gospodarczej, w tym rynku pracy.

Na charakterystyki współczesnych zmian strukturalnych składają się procesy deagraryzacji (spadku znaczenia sektora rolnictwa), a także tercjaryzacji (wzrostu znaczenia sektora usług), a nawet szersze zjawiska serwicyzacyjne (oznaczające wzrost znaczenia procesów, funkcji, czynności i zawodów usługowych w całej gospodarce). Ponadto w zależności od etapu rozwoju można obserwować procesy industrializacji (w krajach rozwijających się) lub deindustrializacji (w krajach o wysokim poziomie rozwoju). Wraz z zaawansowaniem przekształceń na znaczeniu zyskują też zjawiska wykształcania się modelu gospodarki opartej na wiedzy, w której wiedza staje się podstawowym czynnikiem wytwórczym, przesądza o konkurencyjności i decyduje o osiaganym dobrobycie. Ewolucja w kierunku gospodarki opartej na wiedzy jest szczególnie dostrzegalna w państwach najwyżej rozwiniętych, wypracowujących wysoki poziom dochodu na mieszkańca, m.in. dzięki kreacji i powszechnemu wykorzystaniu wiedzy. Gospodarki takie cechuje wysoki poziom kapitału ludzkiego, rozwój nowoczesnych technologii, w tym informacyjno-komunikacyjnych, a także innowacyjność i zdolność do współpracy w układach sieciowych. Nie bez znaczenia dla zaawansowania zmian pozostaje otoczenie instytucjonalne, w tym kreowane w ramach polityki społeczno-ekonomicznej bodźce dla tworzenia i adaptacji wiedzy dla potrzeb gospodarczych.

Gospodarki w celu uzyskania wysokiej konkurencyjności muszą uzyskać dostęp do jak najszerszych zasobów wiedzy i o jak najwyższym poziomie. Niezbędne są więc nie tylko intensywne działania budujące wiedzę w różnych jej postaciach, ale i mechanizmy zapobiegające jej zanikaniu i dezaktualizacji. W sferze zasobów ludzkich konieczne są aktywności tworzące kapitał ludzki, w tym przede wszystkim w zakresie edukacji formalnej i nieformalnej, również w ramach procesów „uczenia się przez działanie”. Równie

${ }^{2}$ A. Zachorowska-Mazurkiewicz, Istota nierówności w procesie rozwoju - podejście instytucjonalne [w:] Wspótczesne wymiary nierówności w procesie globalizacji, red. E. Okoń-Horodyńska, A. ZachorowskaMazurkiewicz, Wydawnictwo Uniwersytetu Jagiellońskiego, Kraków 2011, s. 15, 17.

${ }^{3}$ M. Pokrzywa, Pteć kulturowa a technologie informacyjne i komunikacyjne, [w:] Nierówności spoteczne a wzrost gospodarczy. Społeczeństwo informacyjne - stan i perspektywy rozwoju, red. M.G. Woźniak, Wydawnictwo Uniwersytetu Rzeszowskiego, Rzeszów 2011/22, s. 152.

${ }^{4}$ M. Frąckowiak-Sochańska, (Post)feminizm - dyskurs egalitarny czy narzędzie generowania nierówności? Spór o obszary (nie)równości ptci, [w:] Spór o społeczne znaczenie społecznych nierówności, red. K. Podemski, Wydawnictwo Naukowe UAM, Poznań 2009, s. 302. 
istotne są jednak działania zapobiegające zjawiskom „drenażu mózgów” czy nieuzasadnionemu wyłączeniu zasobów ludzkich ze sfery aktywności gospodarczej lub możliwości pracy. Dlatego tak ważne jest zapewnienie jak najszerszego zatrudnienia osób obu płci i zapobieganie dyskryminacyjnym praktykom rynków pracy. Zjawiska segregacji płci stają się przy tym szczególnie nieuzasadnione w warunkach rozwoju gospodarki opartej na wiedzy, a więc powinny zanikać wraz z przechodzeniem do wyższych etapów rozwoju społeczno-gospodarczego. O ile bowiem w gospodarkach słabo rozwiniętych o możliwościach pracy i jej efektywności często decydują cechy fizyczne - naturalnie różnicujące kobiety i mężczyzn, o tyle w gospodarkach wiedzochłonnych najważniejsze stają się walory intelektualne, a te nie wykazują zależności od płci. Co więcej, ze względu na powszechne w krajach rozwiniętych wyższe wskaźniki wykształcenia kobiet wydaje się, że powinny one mieć silniejszą pozycję na rynku pracy i uzyskiwać większe sukcesy w pracy zawodowej. Różnice w zatrudnieniu osób odmiennej płci powinny więc zanikać wraz z osiąganiem coraz wyższego poziomu rozwoju społeczno-gospodarczego.

Wobec tych uwag celem badawczym podjętym w niniejszym artykule była identyfikacja różnic w trójsektorowej strukturze zatrudnienia kobiet i mężczyzn występujących pomiędzy gospodarkami państw świata. Weryfikacji poddano wyjściową hipotezę badawczą zakładająca, że dysproporcje płci w sektorowej strukturze zaangażowania siły roboczej zmniejszają się wraz z rosnącym poziomem rozwoju społeczno-gospodarczego. Wobec tendencji do tworzenia gospodarki opartej na wiedzy i wzrastającego znaczenia cech intelektualnych pracowników oczekuje się malejących różnic w kierunkach zatrudnienia kobiet i mężczyzn wraz z rosnącym poziomem dochodu na mieszkańca, który odzwierciedla poziom zaawansowania rozwojowego kraju.

Do realizacji wskazanego zadania badawczego wykorzystano dane statystyczne zaczerpnięte $\mathrm{z}$ opracowania Banku Światowego World Development Indicators (WDI2013) ${ }^{5}$. Dostępność wybranych do analizy wskaźników zawęziła grupę porównywanych gospodarek do 96 państw świata, pozostających na zróżnicowanym poziomie rozwojowym.

Poziom rozwoju oceniono na podstawie dochodu narodowego brutto na mieszkańca według parytetu siły nabywczej w 2011 r. Dochód ten stanowił podstawę porównań poszczególnych krajów oraz podziału analizowanych państw na 4 grupy o dochodzie: niskim, średnim niższym, średnim wyższym i wysokim. Granice grup wyznaczono na poziomie dochodu na mieszkańca 10 tys., 20 tys. i 30 tys. dolarów. W ten sposób otrzymano grupy o liczebnościach odpowiednio: 42, 20, 12 i 22 państwa.

Za podstawowy wskaźnik oceny nierówności dochodowych przyjęto współczynnik Giniego, zawierający się w przedziale 0-100. Stanowił on wyjściowy wyznacznik skali dysproporcji występujących w ramach gospodarek państw świata o zróżnicowanym poziomie rozwoju.

Zróżnicowanie płci w zakresie zaangażowania w sektorach rolnictwa, przemysłu i usług oceniono z wykorzystaniem udziału procentowego, a także łącznie dla wszystkich sektorów na podstawie miary zróżnicowania struktur Karola Kukuły w postaci:

$$
v=\frac{\sum_{i=1}^{k}\left|\alpha_{i}-\beta_{i}\right|}{2}
$$

\footnotetext{
${ }^{5}$ Bank Światowy, WDI2013, http://wdi.worldbank.org/tables, tab. 1.1, 2.3, 2.9 (dostęp: 12.05.2013).
} 
gdzie:

$\alpha, \beta$ - udział w strukturze zatrudnienia odpowiednio kobiet i mężczyzn,

$\mathrm{i}=1, \ldots, \mathrm{k}(\mathrm{k}=3)$ - poszczególne sektory działalności gospodarczej (rolnictwo, przemysł, usługi).

Miara ta przyjmuje wartość 0 w sytuacji braku różnic w trójsektorowym rozkładzie zatrudnienia osób o różnej płci i wzrasta do maksymalnego poziomu 100 w sytuacji narastających dysproporcji.

Występowanie współzależności analizowanych zjawisk ekonomicznych weryfikowano z wykorzystaniem współczynników korelacji wraz z oceną ich statystycznej istotności na poziomie $\alpha=0,05$.

\section{WYNIKI ANALIZ}

Uwzględnienie państw świata pozostających na odmiennych etapach rozwoju społeczno-gospodarczego zwraca uwage na różnorodność problemów strukturalnych, z jakimi muszą się one zmierzyć. W badanej grupie znaczne są wyjściowe dysproporcje w poziomie uzyskiwanego dochodu na mieszkańca, przy zmienności rzędu 93\%. Najwyższy poziom dochodu odnotowano w Katarze (86 440 dolarów), najniższy zaś w Liberii (540 dolarów). Wyraźnie zaznacza się koncentracja gospodarek w grupie o najniższych poziomach dochodu. Średni dochód na mieszkańca dla wszystkich 96 państw wyniósł 18 593,02 dolarów, mediana dochodu zaś to 11705 dolarów. Znacznie wyższe dysproporcje dochodowe występują więc pomiędzy państwami bogatszymi, które w zróżnicowanym zakresie rozwijają także model gospodarki opartej na wiedzy.

Znaczące różnice występują również pomiędzy skalą nierówności dochodowych w poszczególnych państwach. Największe dysproporcje mierzone współczynnikiem Giniego zaobserwowano w Namibii (64), najmniejsze zaś w Danii, Szwecji i Japonii (25). Dostrzec można koncentrację państw o największych dysproporcjach dochodowych w grupie krajów najuboższych. Porównanie średniej miary nierówności w poszczególnych grupach państw wskazuje na ich ograniczanie wraz z rosnącą zamożnością (tab. 1). Potwierdza to wartość współczynnika korelacji pomiędzy wskaźnikiem Giniego i dochodem na mieszkańca dla wszystkich analizowanych gospodarek, który przyjął ujemną wartość i okazał się statystycznie istotny (tab. 1, rys. 1). Można więc wnioskować, że ogólny poziom nierówności dochodowych maleje wraz z rosnącym dobrobytem. Zależności te umiejscawiają współczesną gospodarkę światową na opadającym fragmencie krzywej Kuznetsa lub wręcz sugerują występowanie zależności o kształcie litery L z typowym logarytmicznym przebiegiem zjawisk egalitaryzacji dochodów wewnątrzkrajowych wraz z rosnącym dochodem na mieszkańca. 
Rys. 1. Poziom dochodu na mieszkańca i nierówności dochodowych dla 96 państw świata Wykres rozrzutu Gini (1993-2011) względem Dochód narodowy brutto pc PPP Arkusz1 $10 \mathrm{v}^{*} 96 \mathrm{c}$ Gini $(1993-2011)=42,2922-0,0002^{*} x$

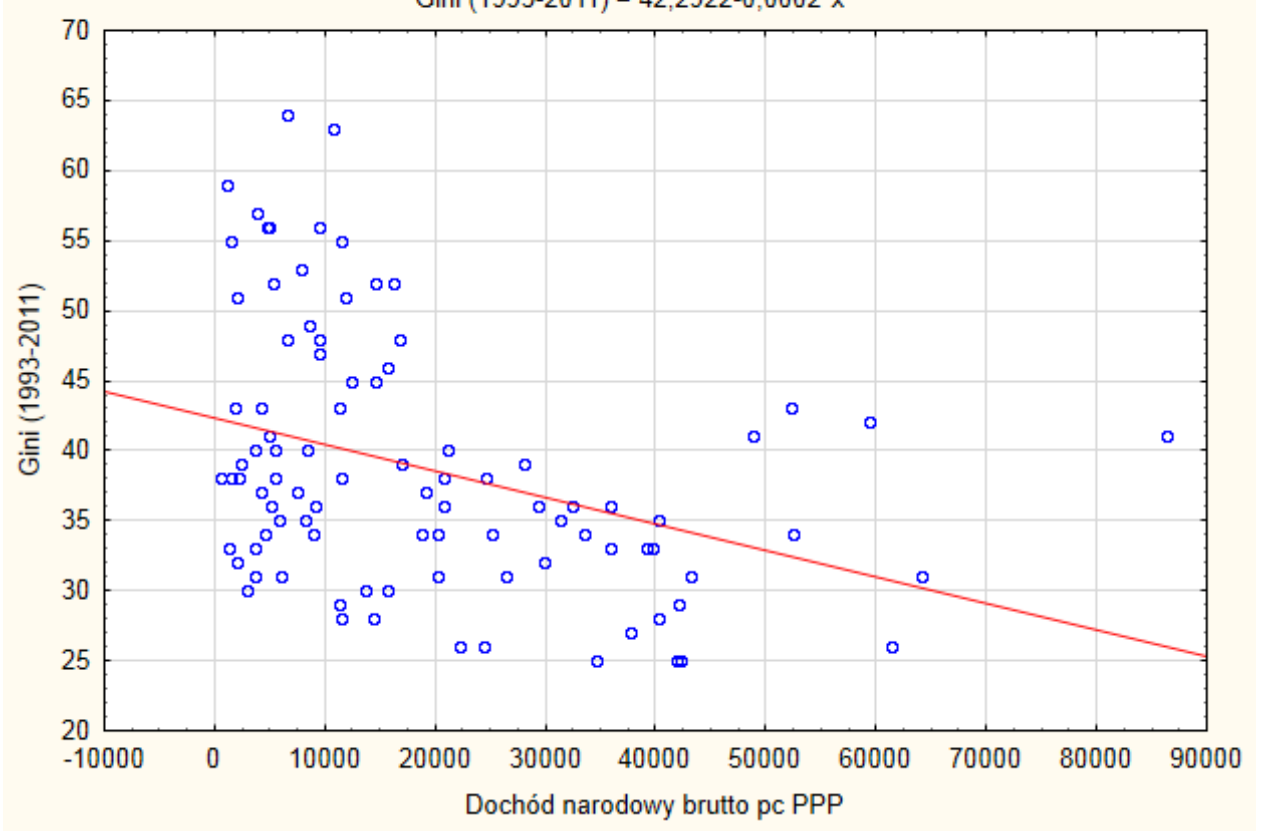

Źródło: obliczenia własne na podstawie danych Banku Światowego, WDI2013, http://wdi.worldbank.org/tables, tab. 1.1, 2.9 (dostęp: 12.05.2013).

Tabela 1. Dochód na mieszkańca i nierówności dochodowe w grupach państw o zróżnicowanej zamożności

\begin{tabular}{|l|l|l|l|l|l|}
\hline & Ogółem & Grupa I & Grupa II & Grupa III & Grupa IV \\
\hline Średni dochód & 18593,02 & 4935,95 & 14486,5 & 24384,17 & 45240 \\
\hline Średni Gini & 38,77 & 42,02 & 41,65 & 33,42 & 32,86 \\
\hline Korelacja & $-0,3564$ & Nieistotna & Nieistotna & Nieistotna & Nieistotna \\
\hline
\end{tabular}

Źródło: obliczenia własne na podstawie danych Banku Światowego, WDI2013, http://wdi.worldbank.org/tables, tab. 1.1, 2.9 (dostęp: 12.05.2013).

Odmienność charakterystyk strukturalnych poszczególnych państw świata odzwierciedlona jest także w zróżnicowaniach rozwoju sektorów aktywności gospodarczej. Zmiany skali zaangażowania siły roboczej są zgodne z koncepcjami trójsektorowymi. Wraz z przechodzeniem do grup o coraz wyższym poziomie dochodu na mieszkańca maleje znaczenie sektora rolnictwa dla zatrudnienia, rośnie, a następnie zmniejsza się rola sektora przemysłu i trwale wzrasta udział sektora usług w zatrudnieniu. Tendencje te dostrzegalne są w analizie zatrudnienia zarówno kobiet, jak i mężczyzn (tab. 2). 
Tabela 2. Odsetek zatrudnionych w trzech sektorach w 96 państwach świata

\begin{tabular}{|l|l|r|r|r|r|r|}
\hline Sektor & Płeć & \multicolumn{1}{c|}{ Ogółem } & Grupa I & Grupa II & Grupa III & Grupa IV \\
\hline \multirow{3}{*}{ Rolnictwo } & Mężczyźni & 21,21 & 36,43 & 16,65 & 7,92 & 3,55 \\
\cline { 2 - 7 } & Kobiety & 20,06 & 37,12 & 12,85 & 6,17 & 1,64 \\
\cline { 2 - 7 } & Różnica & 1,15 & 0,69 & 3,8 & 1,75 & 1,91 \\
\hline \multirow{3}{*}{ Przemysł } & Mężczyźni & 27,81 & 21,12 & 31,8 & 37,17 & 31,86 \\
\cline { 2 - 7 } & Kobiety & 12,86 & 12,02 & 16,5 & 16,17 & 9,36 \\
\cline { 2 - 7 } & Różnica & 14,95 & 9,10 & 15,3 & 21 & 22,5 \\
\hline \multirow{3}{*}{ Usługi } & Mężczyźni & 49,99 & 40,81 & 51,3 & 54,75 & 63,73 \\
\cline { 2 - 7 } & Kobiety & 65,91 & 48,98 & 69,86 & 77,83 & 88,14 \\
\cline { 2 - 7 } & Różnica & 15,92 & 8,17 & 18,55 & 23,08 & 24,41 \\
\hline
\end{tabular}

Źródło: obliczenia własne na podstawie danych Banku Światowego, WDI2013, http://wdi.worldbank.org/tables, tab. 1.1, 2.3 (dostęp: 12.05.2013).

Pomimo podobieństwa kierunków transformacji należy zauważyć występowanie znacznych dysproporcji pomiędzy skalą zaangażowania kobiet i mężczyzn w poszczególnych sektorach. Relatywnie najmniejsze dysproporcje obserwuje się w rolnictwie, w którym zatrudnienie znajduje około $21 \%$ pracujących mężczyzn i $20 \%$ kobiet. Wśród państw najuboższych w sektorze tym zatrudnionych jest minimalnie wyższy odsetek pracujących kobiet. Wraz ze wzrostem zamożności początkowo szybciej zmniejsza się udział zaangażowanych kobiet. W drugiej grupie państw odsetek zatrudnionych mężczyzn w rolnictwie jest o niemal 4 pkt proc. wyższy. Wśród państw najbogatszych różnice te są mniejsze i wynoszą około 2 pkt proc., jednak oznacza to dwukrotnie większy odsetek pracujących w rolnictwie mężczyzn niż kobiet.

W sektorze przemysłu odsetek pracujących mężczyzn jest około dwukrotnie wyższy niż kobiet. Różnice sięgają 15 pkt proc. dla wszystkich analizowanych państw świata. Dysproporcje te dodatkowo narastają wraz z przechodzeniem do grup krajów o wyższym poziomie zamożności z około 9 pkt proc. do niemal 23 pkt proc. Zmniejszenie odsetka pracujących kobiet obserwuje się już w porównaniu drugiej i trzeciej grupy państw, podczas gdy zaangażowanie mężczyzn w przemyśle wzrasta między tymi grupami o ponad 5 pkt proc. Industrializacja stwarza więc miejsca pracy przede wszystkim dla mężczyzn.

Największe dysproporcje w zaangażowaniu osób obu płci występują jednak w sektorze usług i sięgają 16 pkt proc., przy czym sektor trzeci to sektor typowo sfeminizowany. Odsetek zatrudnionych kobiet wzrasta tu z $49 \%$ w państwach najuboższych do $88 \%$ w krajach o najwyższym poziomie dobrobytu. Relacje te dla mężczyzn wynoszą odpowiednio $41 \%$ i $64 \%$. Wraz z zamożnością wzrastają również różnice w zaangażowaniu w usługach kobiet i mężczyzn - z 8 pkt proc. w pierwszej grupie państw do 23 pkt proc. w grupie czwartej.

Porównania te wskazują na występowanie zjawiska rosnących dysproporcji zatrudnienia płci wraz z rozwojem społeczno-gospodarczym państw świata, które w szczególności dostrzegalne są w ramach sektora usług. Zjawisko takie może budzić niepokój ze względu na zanikanie wraz z postępem znaczenia różnic biologicznych między kobietami i mężczyznami. Jak wskazuje Magdalena Pokrzywa dysproporcje te mogą znaleźć wyjaśnienie w istniejących współcześnie stereotypach płci, które odnoszą się głównie do ról społecznych i opierają na społecznie i kulturowo utrwalonym przekonaniu o właściwym dla kobiet i mężczyzn sposobie funkcjonowania w określonych sytuacjach społecznych oraz cechach posiadanych przez kobiety i mężczyzn. Stereotypy te występują również w go- 
spodarkach o zaawansowanych przekształceniach w kierunku gospodarki opartej na wiedzy oraz społeczeństwa informacyjnego i opisują kobiety jako mniej odpowiednie, mniej kompetentne lub mniej zainteresowane dziedzinami technologicznymi. Efekty takich stereotypów dostrzegane są na rynku pracy i mają również wymiar materialny ${ }^{6}$. Jak wskazują analizy prowadzone przez Bank Światowy, różnice płacowe i wydajnościowe występujące pomiędzy osobami odmiennej płci zmniejszyłyby się znacznie, gdyby zostały zlikwidowane różnice w zawodowej i sektorowo-branżowej dystrybucji zatrudnienia kobiet i mężczyzn. Ograniczenie barier dyskryminujących pracę kobiet w określonych sektorach i zawodach w niektórych krajach zwiększyłyby produktywność pracy o ponad $25 \% \%^{7}$.

Sformułowany wniosek o rosnących dysproporcjach płci w sektorowej dystrybucji siły roboczej wraz z rosnącym dobrobytem potwierdza dalsza analiza (rys. 2, tab. 3). Łączna ocena zróżnicowania struktury zatrudnienia kobiet i mężczyzn przeprowadzona na podstawie miary Kukuły wskazuje, że różnice te wzrastają z 20,6 w grupie pierwszej do 24,4 w czwartej grupie państw, a liczby te można interpretować jako średnie różnice odsetka pracujących kobiet i mężczyzn w poszczególnych sektorach. Ponadto korelacja pomiędzy zróżnicowaniem struktur zatrudnienia kobiet i mężczyzn a poziomem dochodu na mieszkańca dla wszystkich państw świata okazała się istotna statystycznie i dodatnia. Oznacza to więc występowanie wzrastających dysproporcji płci wraz ze wzrostem zamożności.

Tabela 3. Dochód na mieszkańca i zróżnicowanie struktur zatrudnienia kobiet i mężczyzn w grupach państw o zróżnicowanej zamożności

\begin{tabular}{|l|l|l|l|l|l|}
\hline & Ogółem & Grupa I & Grupa II & Grupa III & Grupa IV \\
\hline Średni dochód & 18593,02 & 4935,95 & 14486,5 & 24384,17 & 45240 \\
\hline $\begin{array}{l}\text { Średnie dys- } \\
\text { proporcje płci }\end{array}$ & 21,89 & 20,57 & 21,18 & 23,08 & 24,41 \\
\hline Korelacja & 0,2434 & Nieistotna & Nieistotna & Nieistotna & Nieistotna \\
\hline \\
Źródło: obliczenia własne na podstawie danych Banku Światowego, WDI2013, \\
http://wdi.worldbank.org/tables, tab. 1.1, 2.3 (dostęp: 12.05.2013).
\end{tabular}

\footnotetext{
${ }^{6}$ M. Pokrzywa, op. cit., s. 155, 156, 158.

${ }^{7}$ World Development Report 2012. Gender Equality and Development, The World Bank, Washington DC 2011, s. 207.
} 
Rys. 2. Poziom dochodu na mieszkańca i zróżnicowanie struktur zatrudnienia kobiet i mężczyzn dla 96 państw świata

Wykres rozrzutu różnice płci względem Dochód narodowy brutto pc PPP Arkusz1 $10 \mathrm{v}^{*} 96 \mathrm{c}$

różnice płci $=19,7014+0,0001^{*} x$

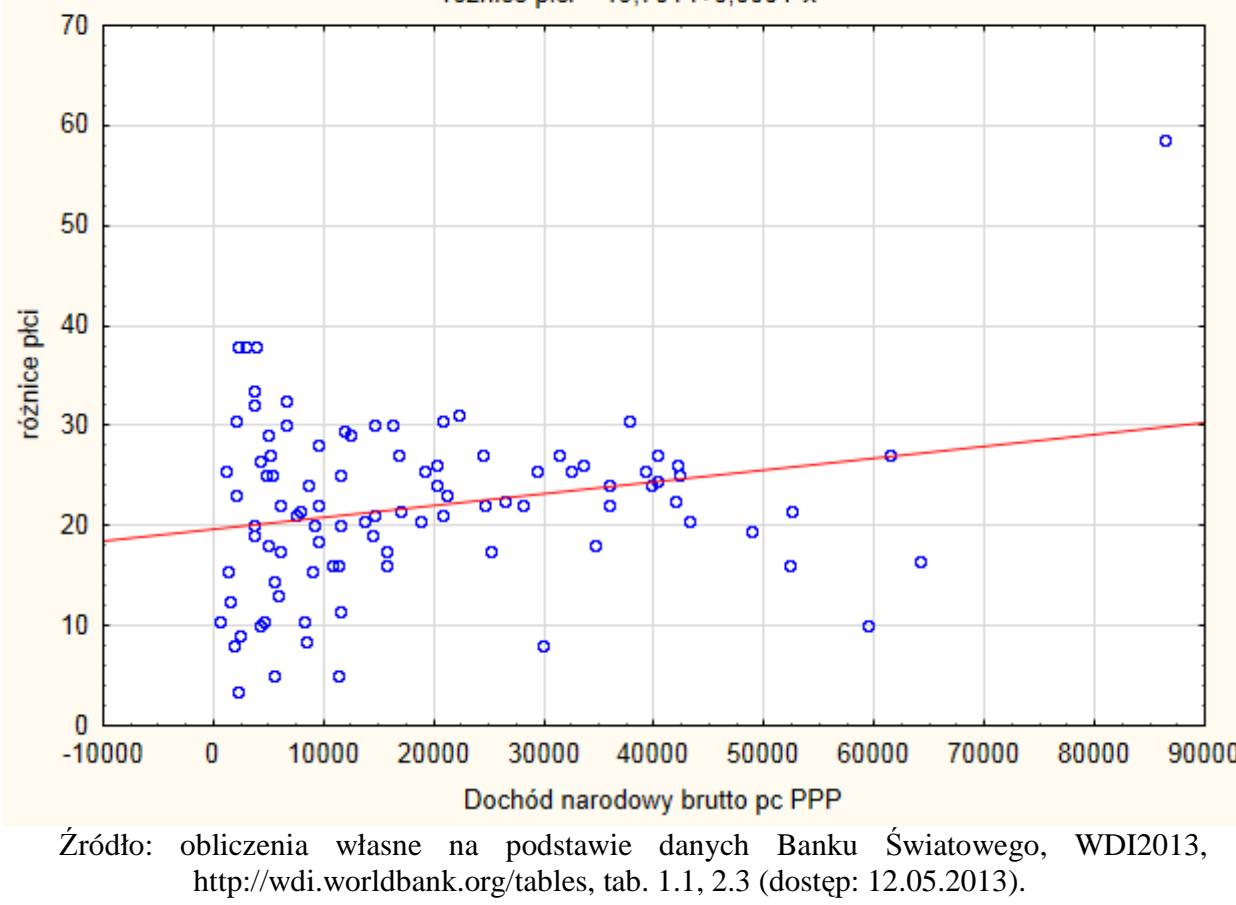

Interesująca jest wyróżniająca się pozycja Kataru, który będąc państwem o najwyższym średnim dochodzie, jest jednocześnie gospodarką o najwyższych dysproporcjach w strukturze zatrudnienia osób o różnej płci (miara Kukuły przyjmuje wartość 58,5 wobec średniej 21,9 i mediany 22). W tym naftowym emiracie kobiety zaangażowane są właściwie wyłącznie w sferze usług (96\% pracujących kobiet). Znaczne zróżnicowanie dystrybucji pracy kobiet i mężczyzn odnotowuje się także w ubogich krajach, takich jak arabski Jemen i Pakistan czy środkowoamerykański Honduras (miara Kukuły na poziomie 38). $\mathrm{W}$ islamskich Jemenie i Pakistanie kobiety zatrudnione są głównie w rolnictwie, które pozostaje ważnym obszarem gospodarki tych państw. W Hondurasie w sektorze rolnictwa dominują mężczyźni, podczas gdy podstawowym obszarem zatrudnienia kobiet są usługi. Sytuacja ta zwraca uwagę na wpływ rozwiązań instytucjonalnych na status kobiet w społeczeństwie.

Pozycja na rynku pracy jest często odzwierciedleniem szerszej marginalizacji kobiet i ograniczenia wielu ich praw. Ważne znaczenie dla równoprawnego zatrudnienia kobiet odgrywają kultura, religia, system sprawowania władzy czy doświadczenia historyczne danego społeczeństwa, a także realizowana przez państwo polityka społeczna. Bank Światowy wśród najistotniejszych czynników ograniczających równość płci wskazuje: sposób 
wykorzystania czasu, dostęp do zasobów, kredytów i inne błędy rynków oraz bariery instytucjonalne (formalne i nieformalne) ${ }^{8}$.

Samo uczestnictwo w pracy zawodowej jest silnie warunkowane przez płeć i związane z nią role społeczne. Według raportu OECD na całym świecie wskaźnik zatrudnienia kobiet zależy od liczby i wieku posiadanych dzieci ${ }^{9}$. Aktywność zawodową kobiet ogranicza m.in. brak systemu opieki nad dziećmi. Co więcej, raport unijny wskazuje, że zjawiska recesyjne w większym stopniu dotykają kobiet niż mężczyzn, gdyż częściej pracują one na stanowiskach bardziej zagrożonych, w tym w niepełnym wymiarze godzin czy w ramach umów na czas określony, które nie gwarantują pewności zatrudnienia ${ }^{10}$. Rozwiązania prawne upowszechniane w krajach najwyżej rozwiniętych, a ukierunkowane na ochronę socjalną kobiet często odnoszą skutki utrwalające dysproporcje płci. Podnosząc koszty zatrudnienia kobiet dla pracodawców, sprawiają, że stają się one mniej atrakcyjne na rynku pracy, a w efekcie rzadziej zatrudniane, zatrudniane na mniej korzystnych warunkach i częściej zwalniane. Niedoskonałość, a często brak możliwości skorzystania z rozwiązań pozwalających godzić obowiązki rodzinne i zawodowe kobiet często wymuszają ich przesunięcie do sfery bierności zawodowej.

Niewątpliwie jednak sytuacja kobiet na rynku pracy wynika również z mentalności samych kobiet. Istniejące stereotypy płci warunkują nie tylko postawy mężczyzn wobec kobiet, ale i samopostrzeganie oraz życiowe wybory kobiet. Stereotypy płci mogą także częściowo wyjaśniać międzysektorowe różnice w dystrybucji siły roboczej. Feminizacja sektora usług rosnąca wraz z poziomem dobrobytu wskazuje, że kobiety wciąż częściej są zatrudniane w zawodach o charakterze opiekuńczym i wymagającym budowania więzi emocjonalnej oraz relacji międzyosobowych. Niestety często są to również zajęcia niżej opłacane. Ponadto zjawiska segregacji poziomej, warunkującej dostęp do specyficznych zawodów współistnieją z segregacją w wymiarze pionowym, która ogranicza możliwości awansu i rozwoju zawodowego kobiet. Wiele ze wskazanych czynników wzajemnie się nakłada, warunkując rzeczywisty rozkład międzysektorowego zaangażowania pracowników różnej płci.

\section{PODSUMOWANIE}

Przedstawione w opracowaniu wyniki analiz trójsektorowej struktury zatrudnienia kobiet i mężczyzn oparte na statystykach opisujących gospodarki państw świata, pozostających na zróżnicowanym poziomie rozwoju społeczno-gospodarczego zaprzeczają postawionej na początku rozważań hipotezie o minimalizacji różnic powstających na tle odmienności płci. Wręcz przeciwnie - dysproporcje w sektorowej dystrybucji siły roboczej rosną wraz z przechodzeniem do wyższego poziomu dobrobytu. Zjawisko to jest obserwowane mimo ogólnej tendencji do zmniejszania się wewnątrzkrajowych nierówności społecznych postrzeganych w aspekcie dochodowym.

Sytuacja ta wskazywać może na wciąż nieznaczne zaawansowanie rozwoju modelu gospodarki opartej na wiedzy, w której o zatrudnialności decydują przymioty intelektualne. Kobiety, które w najbardziej rozwiniętych krajach świata często są lepiej wykształco-

\footnotetext{
${ }^{8}$ World Development Report 2012..., s. 17-18.

${ }^{9}$ M. Rękas, Kobiety na rynku pracy a elastyczne formy zatrudnienia, [w:] Nierówności spoteczne a wzrost gospodarczy. Spójność spoteczno-ekonomiczna a modernizacja gospodarki, red. M.G. Woźniak, Wydawnictwo Uniwersytetu Rzeszowskiego, Rzeszów 2010/16, s. 325.

${ }^{10}$ Ibidem, s. 326.
} 
ne niż mężczyźni, pozostają jednak grupą o ograniczonej dostępności do wykonywania wielu zawodów i o trudniejszej sytuacji na rynku pracy. Dysproporcje te mogą być wynikiem występującej dyskryminacji, w tym segregacji o charakterze poziomym.

Silne dysproporcje w strukturze zatrudnienia kobiet i mężczyzn są szczególnie wyraźne w krajach najzamożniejszych, o rozbudowanym systemie opiekuńczym. Wdrażane rozwiązania instytucjonalne mają na celu zapewnienie bezpieczeństwa i ochrony dla kobiet. Dostrzegają one odmienność męskich i żeńskich ról społecznych oraz predyspozycji biologicznych. Stąd też niejako utrwalają istniejące stereotypy płci i zwiększają dysproporcje w branżowej strukturze zaangażowania siły roboczej. W efekcie dla potencjalnych pracodawców oferowany przez kobiety wysoki poziom kapitału ludzkiego okazuje się mniej atrakcyjny wobec wysokiego prawdopodobieństwa dłuższej absencji w pracy związanej z odgrywaniem ról rodzicielskich. Świadczy to zarówno o utrzymywaniu się tradycyjnego modelu relacji społecznych związanych z życiem rodzinnym, jak i krótkookresowego podejścia przedsiębiorców do realizowanej działalności gospodarczej. Wynikać to może więc z nakładania się kulturowych stereotypów płci, jak i wyników rachunku ekonomicznego pracodawców prowadzonego dla krótkich horyzontów czasowych i pozostającego pod wpływem rozwiązań prawnych generujących dodatkowe koszty w sytuacji zatrudnienia kobiet.

W wielu gospodarkach pozostających w kręgu kultury pozaeuropejskiej, w tym przede wszystkim arabskiej o podstawach islamskich, społeczna rola kobiet pozostaje ograniczona do obowiązków domowych. Rzadkim zjawiskiem jest zawodowe zatrudnienie kobiet, a jeśli jest ono podejmowane, to jedynie $w$ ograniczonym spektrum działalności gospodarczych. Z kolei w licznych najuboższych państwach świata praca kobiet jest realizowana ze względu na przymus biologiczny zapewnienia przetrwania rodzinie. $\mathrm{W}$ takich sytuacjach, niezależnie od możliwości psychofizycznych, kobiety i mężczyźni wykonują podobne zajęcia.

Zaobserwowane w przekroju analizowanych państw świata różnice w zaangażowaniu siły roboczej odmiennych płci są związane przede wszystkim z feminizacją sektora usług, który zyskuje na znaczeniu w gospodarkach państw o najwyższym poziomie dobrobytu. Wcześniejszy etap uprzemysłowienia wiąże się natomiast z zatrudnianiem w większym stopniu mężczyzn. Tradycyjnie różnice te można częściowo uzasadnić predyspozycjami fizycznymi osób różnej płci. Współcześnie jednak chodzi raczej o różnice o charakterze emocjonalnym $\mathrm{i}$ dysproporcje kreowane $\mathrm{w}$ procesie socjalizacji przypisujące kobietom role opiekuńcze i wychowawcze oraz cechy, takie jak empatia, współczucie czy wrażliwość.

Zwracając uwagę na wysoki odsetek pracujących kobiet zaangażowanych w sektorze usług, należy dostrzec znaczny udział sektora publicznego w realizacji świadczeń usługowych. Jego funkcjonowanie często w mniejszym zakresie oparte jest na rachunku ekonomicznym, a ukierunkowane na realizację celów społecznych. Jednocześnie zatrudnienie $\mathrm{w}$ wielu zawodach usługowych $\mathrm{w}$ ramach sektora publicznego wiąże się $\mathrm{z}$ relatywnie niskim opłaceniem pracy, pozostaje więc zajęciem mało konkurencyjnym. Wydaje się jednak, że sytuacja ta będzie stopniowo się zmieniać wraz z zapotrzebowaniem i przeobrażeniami społeczno-demograficznymi. 


\section{LITERATURA}

[1] Bank Światowy, WDI2013, http://wdi.worldbank.org/tables, tab. 1.1, 2.3, 2.9 (dostęp: 12.05.2013).

[2] Frąckowiak-Sochańska M., (Post)feminizm - dyskurs egalitarny czy narzędzie generowania nierówności? Spór o obszary (nie)równości ptci, [w:] Spór o spoteczne znaczenie spotecznych nierówności, red. K. Podemski, Wydawnictwo Naukowe UAM, Poznań 2009.

[3] Pokrzywa M., Pteć kulturowa a technologie informacyjne i komunikacyjne, [w:] Nierówności społeczne a wzrost gospodarczy. Spoteczeństwo informacyjne - stan i perspektywy rozwoju, red. M.G. Woźniak, Wydawnictwo Uniwersytetu Rzeszowskiego, Rzeszów 2011/22.

[4] Rękas M., Kobiety na rynku pracy a elastyczne formy zatrudnienia, [w:] Nierówności spoteczne a wzrost gospodarczy. Spójność społeczno-ekonomiczna a modernizacja gospodarki, red. M.G. Woźniak, Wydawnictwo Uniwersytetu Rzeszowskiego, Rzeszów 2010/16.

[5] World Development Report 2012. Gender Equality and Development, The World Bank, Washington DC 2011.

[6] Zachorowska-Mazurkiewicz A., Istota nierówności w procesie rozwoju - podejście instytucjonalne, [w:] Wspótczesne wymiary nierówności w procesie globalizacji, red. E. OkońHorodyńska, A. Zachorowska-Mazurkiewicz, Wydawnictwo Uniwersytetu Jagiellońskiego, Kraków 2011.

\section{WORLD DISPARITIES IN SECTORAL STRUCTURE OF EMPLOYMENT BE- TWEEN MEN AND WOMEN}

Processes of globalisation accelerate structural changes that create postindustrial economies based on knowledge where service relations dominate. They also influence changes in social relations that specify position on a labour market of persons of different genders and modify spheres of existence of modern social inequalities.

Concerning the changes, the study presents research about differences in three-sectoral structure of employment between women and men that exist in economies of countries around the world. There is taken an analysis of the differences between groups of countries that are characterized by different level of socio-economic development, which is specified by level of gross national income per capita. There is verified a thesis that disparities between different genders are diminishing concerning engagement in sectors of agriculture, industry and services along with growing level of welfare. This direction of changes would be derived from growing importance of intellectual features of potential employees and their knowledge for possibilities of employment. This would suggest diminishing gender stereotypes and cultural differences in perceiving social roles of women and men.

The presented results indicate, however, growing disparities in the sphere of employment between women and men along with growing level of income per capita. The data prove high feminization of service sector and creation of industrial workplaces that are favourable for men. The results suggest still low level of development of knowledge based economies, domination of gender stereotypes. They also indicate creation of new lines of social division and deforming character of social policy influence.

Keywords: structure of employment, gender, economic sectors

\section{DOI: 10.7862/rz.2013.mmr.42}

Tekst złożono w redakcji: wrzesień 2013

Przyjęto do druku: grudzień 2013 